Poland

\section{More trials lie ahead}

FOUR members of the former "Committee of Social Self-Defence" (KOR, the leading dissident group in Poland during the late 1970 s), who served as "intellectual advisers" to Solidarity, face trial in the near future on charges of "undertaking preparatory actions aimed at the overthrowing by force of the constitutional system of the Polish people's Republic'. The four - Jacek Kuron (historian), Adam Michnik (historian), Henryk Wujec (physicist) and Zbigniew Romaszewski (physicist) - are named in an indictment delivered to the Warsaw Military Court on 29 September.

The wording of the indictment is something of a suprise. Since the first accusations in August 1982, the Polish media have taken the line that KOR members were political agents, paid by "Western centres of ideological diversion", who had attempted to hijack the genuine working class initiatives which led to the foundation of Solidarity and to turn them against the socialist state. Last week, however, Mr Jerzy Urban, the official government press spokesman, said that the KOR members are charged only with "preparing" a coup, while seven leading Solidarity activists will be charged in due course with actually "organizing" a coup.

What has led to this change of approach is not clear, but it may be partly due to the various appeals and petitions organized by scholars abroad which have argued that the aims of KOR were essentially non-violent and stressed civil rights and social reform.

Vera Rich

- AN extract from a letter from a Polish scientist to Nature:

"Some time ago, you wrote in Nature about the Polish physicist Zbigniew Romaszewski, from the Institute of Nuclear Physics of the Polish Academy of Sciences. You wrote then that he was sentenced to $4 \frac{1}{2}$ years in prison for his work in "Radio Solidarity" . . . But he is facing another trial for his former work in KOR. . . So now he is both a "pre-trial" and "post-triai" "prisoner at the same time. And for this reason he is suffering from severe malnutrition. He has already lost $17 \mathrm{~kg}$. The food in prison is not only very unappetizing, it is also insufficient in terms of quality and quantity. So families provide prisoners with additional food. The regulations are different for pre- and posttrial people. A pre-trial prisoner is allowed to receive one food parcel a month, delivered to the office of the jail. A posttrial prisoner is allowed to receive additional food during visits by family members, but not to receive parcels. Because Mr Romaszewski is both a posttrial and a pre-trial person, he is not allowed to receive any extra food at all."
East Germany

\section{Engineers gain prestige}

THE tendency for engineering to be university level, however, although the regarded as second best to more academic subjects is worrying many governments in both the West and in the Eastern bloc countries. The solution being tried in East Germany is to upgrade all engineering courses to university level. The changes, announced by the Minister of Higher and Vocational Education, Dr Hans-Joachim Boehme, are to be introduced gradually over the next five years and will entail a virtually compete rewriting of textbooks as well as considerable outlay in re-equipping engineering courses and departments. The changes are necessary, Dr Boehme has implied, if the country's future requirements of trained engineering personnel are to be met.

At present, sub-university level engineering tuition in East Germany takes two forms. Technical schools (Fachschulen) offer three-year courses, with a strong practical orientation (the last semester being devoted entirely to practical work in the future place of employment). There are also ten specialized engineering colleges, which train skilled engineering workers for those branches of industry which require a good knowledge of basic science as well as the production process. The new scheme will, presumably, upgrade these colleges to university level.

The main difference between the present sub-university and university courses is that of educational theory. Engineering colleges and Fachschulen provide courses which are basically job-related. At the

\section{Engineers march}

THE Engineering Council, now the main forum for the profession in Britain, is the latest body to put forward its recipe for improving the competitiveness of British industry. It believes that companies' attitudes towards investment in new technologies would be sharpened if they could be persuaded to include in their annual reports technical reviews of their objectives and capabilities. In time, the council hopes, such reviews would become something of a status symbol among manufacturing companies, and lead to increased interest from investors.

There is a trend towards increasing militancy among engineers in Britain. Many believe that their profession is undervalued, and that provision for education in some areas, particularly production engineering, is inadequate. Launching the Engineering Council's latest initiative, Sir Kenneth Corfield, its chairman, painted a depressing picture of the decline in British manufacturing capacity. He argued that many companies are mistakenly relying on out-dated equipment: in today's economic theoretical socialist rationale treats university education primarily as a means of providing the economy with the necessary experts, and although, in the later terms of their four or five year course, students are assigned a practical research project, care is taken to avoid training university students for a specific job. East German industry is advancing so rapidly, it is explained, that too early a specialization may mean the production of graduates qualified only in an obsolescent technology. The aim is rather to produce graduates with a wide range of competence and what the educational planners refer to as "independence" and "creativity".

"Independence", which in this context means the ability to initiate and carry out research without constant supervision, was particularly stressed as an aim for the coming academic year in a review of the current state of the universities given by $\mathrm{Dr}$ Boehme to mark the opening of the new academic year. "Creativity"' likewise was stressed in a recent announcement from the Magdeburg Technical College, that $\mathrm{Dr}$ Hubert Mecke, head of the department of electrical engineering has introduced seminars in the technique of invention. In these courses, it appears, young engineers analyse new inventions, identifying the novelty, discuss the need for this innovation and speculate why the inventor chose this means of solving the problem, and also study the complexities of registering a patent.

Vera Rich

conditions products must capture world unlikely to be achieved unless the best technology is used. The council believes that is essential to bring about a change of attitudes among the higher echelons of management.

In order to provide a lead, the council has published a new booklet explaining include. There is strong emphasis on competitors, and anticipating market demand. Companies should also, according to the council, be more aware of the value of taking up marketable ideas and technologies from outside sources.

A total of $\mathbf{2 0}$ guinea pig companies have already agreed to undertake technical reviews along the lines the council is suggesting. Sir Kenneth admitted that most of these are companies with advanced technical capabilities who would probably have nothing to fear from this sort of soulsearching - but he hopes that as investing institutions get used to the idea of appraising technical matters, others will feel obliged to follow suit.

Tim Beardsley markets to be successful, and this is what it thinks a technical review should assessing the technological capabilities of 